\title{
PROBLEMS WITH APPLYING
}

\section{TOPOGRAPHICALLY DRIVEN FLOW TO}

\section{GENESIS OF THE UPPER MISSISSIPPI VALLEY ZINC-LEAD DISTRICT AND TO}

\section{FLUID FLOW IN THE ILLINOIS BASIN}

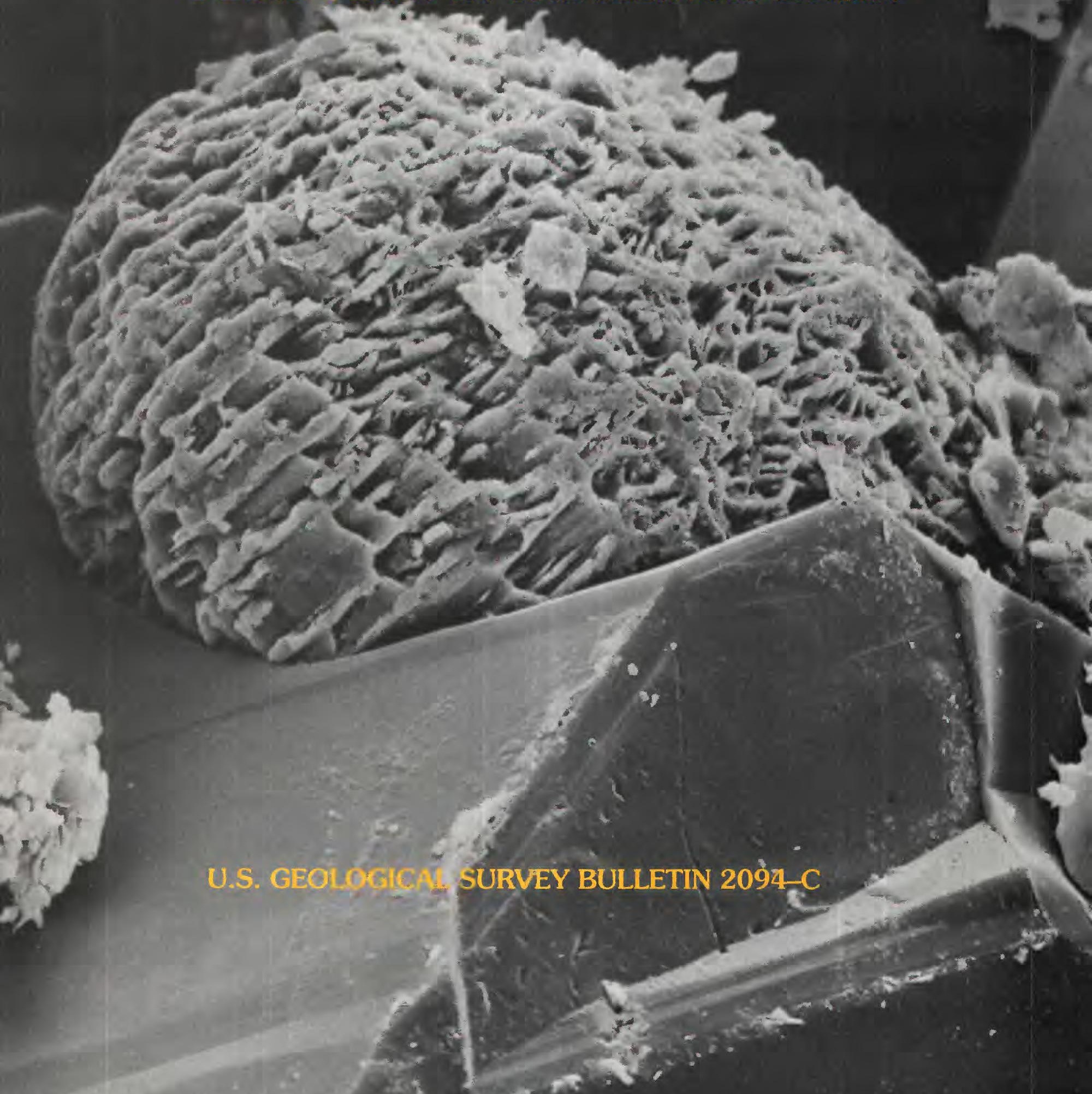


Cover. Leached ilmenite grain approximately 60 microns in diameter surrounded by quartz overgrowth in Lower Pennsylvanian sandstone in Indiana. Quartz overgrowths occlude much of the pore space in these rocks. Sample collected by Paula Hansley, U.S. Geological Survey. 


\section{Problems with Applying}

Topographically Driven Flow to

Genesis of the Upper Mississippi Valley

Zinc-Lead District and to

Fluid Flow in the Illinois Basin

By Charles S. Spirakis

EVOLUTION OF SEDIMENTARY BASINS-ILLINOIS BASIN

Jennie L. Ridgley, Project Coordinator

U.S. GEOLOGICAL SURVEY BULLETIN 2094-C

A multidisciplinary approach to research studies of sedimentary rocks and their constituents and the evolution of sedimentary basins, both ancient and modern 


\title{
U.S. DEPARTMENT OF THE INTERIOR BRUCE BABBITT, Secretary
}

\author{
U.S. GEOLOGICAL SURVEY
}

Gordon P. Eaton, Director

For sale by U.S. Geological Survey, Information Services

Box 25286, Federal Center

Denver, CO 80225

\begin{abstract}
Any use of trade, product, or firm names in this publication is for descriptive purposes only and does not imply endorsement by the U.S. Government
\end{abstract}

\section{Library of Congress Cataloging-in-Publication Data}

Spirakis, Charles S.

Problems with applying topographically driven flow to genesis of the Upper Mississippi Valley zinc-lead district and to fluid flow in the Illinois Basin / by Charles S. Spirakis.

p. cm.-(Evolution of sedimentary basins-Illinois Basin; C)

(U.S. Geological Survey bulletin; 2094)

Includes bibliographical references.

Supt. of Docs. no.: I 19.3:2094-C

1. Metasomatism (Mineralogy)-Illinois Basin. 2. Terrestrial head flow-Illinois

Basin. 3. Zinc ores-Illinois Basin. 4. Lead ores-Illinois Basin. I. Title.

II. Series. III. Series: U.S. Geological Survey Bulletin ; 2094.

QE75.B9 no. 2094-C

QE364.2.M4)

$557.3 s-d c 20)$

[549]

95-9919 


\section{CONTENTS}

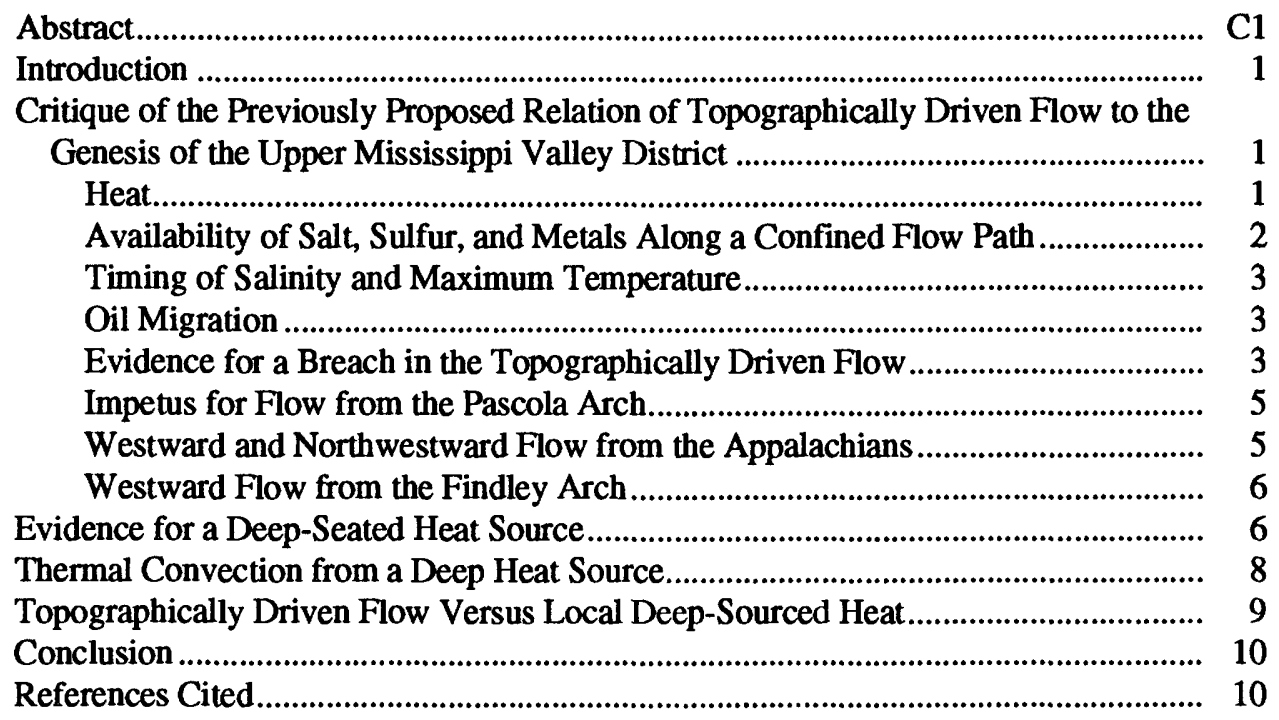

\section{FIGURES}

1,2. Maps showing:

1. Distribution of oil and thermal maturity of New Albany source rock, Illinois and surrounding area

2. Locations of drillholes UPH-1 and UPH-3 and zone of positive magnetic anomalies, north-central United States

3. Schematic cross section showing faulting of uranium- and thorium-enriched basement rock beneath Upper Mississippi Valley district to release pent-up radiogenic heat, drive thermal convection of basinal brines, leach radiogenic lead from basement rock, and deposit radiogenic lead in ores 



\title{
Problems with Applying Topographically Driven Flow to Genesis of the Upper Mississippi Valley Zinc-Lead District and to Fluid Flow in the Illinois Basin
}

\author{
By Charles S. Spirakis
}

\begin{abstract}
Topographically driven ground-water flow and other processes that involve dewatering of basins fail to account for the temperatures indicated by fluid inclusion and sulfur isotope studies in the Upper Mississippi Valley zinc-lead district on the northern edge of the Illinois Basin. If the required temperatures cannot be attained by heat supplied from the basin, the only other source of heat is from below. Gravity and magnetic data, traces of fluorite in basement rocks, and the presence of strike-slip faults in the district suggest that an ancient fault system is present under the district. Reactivation of these faults by Permian continental collision may have opened routes for the deep circulation of water, produced thermal convection systems involving basinal brines, and established conditions for redistribution of elements into Mississippi Valley-type ore deposits. Continental collision is likely to have reactivated faults simultaneously throughout the midcontinent and may account for the similar age of ores in several districts. Thermal anomalies associated with these convecting systems have implications for many aspects of diagenesis in the continental interior.
\end{abstract}

\section{INTRODUCTION}

One of the problems in the genesis of Mississippi Valley-type lead-zinc deposits is a source of heat. For the Illinois-Kentucky district, an intrusion at Hicks dome has long been accepted as a heat source; zoning of ore-related elements and isotopes (Hall and Heyl, 1968) and of fluid inclusion temperatures (Taylor and others, 1992) support this contention. The location of the Hansonburg district along the Rio Grande graben in New Mexico suggests that fluids heated at depth and conducted along faults of the graben may have provided heat for this district. In many districts, however, there is no obvious local heat source, and the long-distance transport of basinal brines heated in the deep parts of sedimentary basins has been suggested as a possible heat source. A compaction-driven, episodic dewatering of shale-rich basins has been proposed as a mechanism to deliver heat to ore districts (Cathles and Smith, 1983); however, a mathematical evaluation of the model (Bethke, 1986) shows that the model is very unlikely to apply to slowly subsiding, shale-poor basins such as the Illinois Basin. Bethke (1986) and Garven and others (1993) discussed the limitations of other processes suggested to transport heat from basins and, as alternatives, proposed models in which topographically driven flow transported heat to the Upper Mississippi Valley district.

\section{CRITIQUE OF THE PREVIOUSLY PROPOSED RELATION OF TOPOGRAPHICALLY DRIVEN FLOW TO THE GENESIS OF THE UPPER MISSISSIPPI VALLEY DISTRICT}

According to Bethke (1986), uplift of the Pascola arch to the south of the Illinois Basin created a topographically driven flow system, operating from the Permian into the Cretaceous, that flushed meteoric water from the Pascola arch through the deep and hot parts of the basin and on to the Upper Mississippi Valley district on the northern side of the basin. Although timing of the post-Pennsylvanian and pre-Late Cretaceous uplift (Marcher and Stearns, 1962), and of the Permian mineralizing event (270 Ma) (Brannon and others, 1992) are compatible, there are several problems with the proposal.

\section{HEAT}

It is not clear if topographically driven flow from the Pascola arch could provide sufficient heat (either intensity [temperature] or quantity [as measured in calories]) to accommodate mineralization. The first indication of how hot the mineralization event was in the Upper Mississippi Valley district was provided by a study of the fractionation of sulfur isotopes between co-precipitated galena and sphalerite (Pinckney and Rafter, 1972), which suggests that early stages of sulfide mineralization in the Booty and Elmo mines 
formed at $155^{\circ} \mathrm{C}-260^{\circ} \mathrm{C}$ (average of 12 sample pairs, $193^{\circ} \mathrm{C}$ ). McLimans (1977) included sulfur isotope geothermometry in his study of the district and found that sulfides precipitated at temperatures as high as $227^{\circ} \mathrm{C}$. Although samples in both of these studies were carefully selected, traces of impurities and disagreement among researchers on fractionation factors between sulfur minerals could affect the results, and the temperatures must be considered with caution. Geothermometry based on fluid inclusion studies (McLimans, 1977, and unpublished studies by T. Casadevall and N. Susak cited therein) is in good agreement with the sulfur isotope geothermometry and indicates that temperatures during mineralization in the Hayden mine of the Upper Mississippi Valley district were as high as $220^{\circ} \mathrm{C}$. (Paleoreconstructions cited in McLimans indicate that the depth of burial at the time of mineralization was $200-762 \mathrm{~m}$; thus, the maximum pressure correction to these temperatures is $12^{\circ} \mathrm{C}$.) Data in the study indicating temperatures as high as $160^{\circ} \mathrm{C}$ are abundant, and higher temperature data constitute only a few percent of the measurements, but, as McLimans pointed out, much of the early- and middle-stage sphalerite was too dark in color for fluid inclusion studies, and additional high-temperature results may have been hidden by the dark color. The abundance of iron-rich (marmatitic) sphalerite (Heyl, 1983) and the alteration of clays in the ore zones (Heyl and others, 1964) also suggest temperatures near $200^{\circ} \mathrm{C}$. The maximum temperature obtainable by topographically driven flow from the Pascola arch is, however, only $120^{\circ} \mathrm{C}$ (Bethke, 1986), and an analysis by Deming and Nunn (1991) suggests that the maximum temperature is even less. Thus, the model lacks the required intensity of heat, and the quantity of heat may also be lacking.

An immense amount of heat is needed to heat the influxing meteoric water and the rocks along the hypothesized 700-km-long flow path and to accommodate the loss of heat to the surface during transport, and evidence of such a hot, migrating solution is lacking. Vitrinite reflectance of the Upper Devonian and Lower Mississippian New Albany Shale (Cluff and Byrnes, 1990) and thermal maturity of Middle Pennsylvanian Herrin Coal Member of the Carbondale Formation (Damberger, 1971) do not indicate prolonged exposure to $220^{\circ} \mathrm{C}$ solutions in the basin; however, it is possible that a short-lived pulse of hot fluid passed without affecting the vitrinite reflectance or maturity of coals, and there is evidence that the mineralizing event in the Upper Mississippi Valley district was short. From studies of the thermal maturity of organic matter in the district, Hatch and others (1986) concluded that the mineralizing event was of short duration; Sangster (1989) reached the same conclusion on the basis of conodont coloration. Lavery and Barnes (1971) used the dispersion of zinc into wallrocks to estimate that mineralization lasted about 250,000 years; Gize and Barnes (1987) considered the thermal maturity of organic matter in the ores to be consistent with an event of 250,000 years. The duration of topographically driven flow is dependent, however, on the uplift and erosion of mountain ranges and hence is not compatible with short-term events. The problems of the required amount of heat and of the lack of evidence for its transit may be minimized by confining flow to a narrow, highly permeable path. In applying the topographically driven flow model to the migration of oil in the Illinois Basin (Bethke and others, 1991) and in response to a question on how to conserve heat as the mineralizing fluid migrated to the Upper Mississippi Valley district (Paduca Conterminous U.S. Mineral Assessment Program/Illinois Basin consortium meeting, St. Louis, 1992), Bethke suggested that dolomitized and karstified rocks just below the sub-Kaskaskia unconformity provided the most likely highly permeable flow path and that most flow was confined to such highly permeable paths. Although this flow path may minimize the problem of the amount of heat, it is very unlikely to provide a source of elements involved in formation of the ore deposits.

\section{A VAILABILITY OF SALT, SULFUR, AND METALS ALONG A CONFINED FLOW PATH}

Mineralizing solutions during genesis of the Upper Mississippi Valley district were highly saline (about 20 percent $\mathrm{NaCl}$ ) and their volumes huge. For the Viburnum trend of southeast Missouri, Sverjensky (1981) estimated that $2,000-32,000 \mathrm{~km}^{3}$ of mineralizing fluid was involved in ore genesis. This estimate is based on the solubility of metals in sulfide solutions. An independent minimum estimate of the volume of fluid involved in the genesis of these deposits can be obtained by considering the volume of pore fluid that was flushed from the Upper Mississippi Valley district. The area of the Upper Mississippi Valley district is about 4,000 $\mathrm{mi}^{2}$ (Heyl and others, 1959), or about $10,000 \mathrm{~km}^{2}$. If at the time of mineralization the total sedimentary column was $1 \mathrm{~km}$ thick and had a porosity of 10 percent, then simply flushing the initial pore water from the district would require 1,000 $\mathrm{km}^{3}$ of water. Therefore, the estimate of $2,000 \mathrm{~km}^{3}$ is not unreasonable. If a similar volume of water was involved in the genesis of the Upper Mississippi Valley district (which contained an amount of ore similar to that in the Viburnum trend), then at least $200 \mathrm{~km}^{3}$ of salt (20 percent of $2,000 \mathrm{~km}^{3}$ of water, divided by 2 because the density of salt is twice that of water) had to be leached along the path of the topographically driven flow. Obtaining that much salt from the Illinois Basin is a problem: the basin is not known to contain salt deposits. Obtaining that much salt from the rocks along the sub-Kaskaskia unconformity is particularly difficult because even if some salt was present in these rocks, it would have been leached as the unconformity formed and therefore would not be available to the mineralizing solution. The unconformity is also an unlikely source of sulfur. As with salt, any evaporitic sulfur would have been leached during the Devonian as the unconformity formed; any pyritic sulfur 
would have been oxidized and leached together with the evaporitic sulfur. Metals are also likely to have been leached as the unconformity formed. Thus, in order to obtain the elements needed for the mineralizing solution, the solution must communicate with the rocks outside of the channelized path along the unconformity; however, the more communication with other rocks, the less effective channelization is at conserving heat. Furthermore, the proposed channelized flow path is within a sequence of rocks laying between the two most effective aquitars in the basin, the New Albany Shale above and the Maquoketa Shale below. No evaporites are known within this sequence, and, according to the description in Bethke and others (1991), rocks within this sequence have been mostly karstified and weathered. Hence, they have been leached of elements needed for the ores.

\section{TIMING OF SALINITY AND MAXIMUM TEMPERATURE}

Deming and Nunn (1991) pointed out that, as the topography rose on the edge of a basin, fluids would begin to flow slowly and then more rapidly over time as relief increased. They also pointed out that initial flow rates were insufficient to efficiently transport heat to the basin's margins but did transport salt. Their calculations indicate that, by the time flow rates were optimal to transport heat, the salt supply of a typical basin was likely to have been exhausted. The Illinois Basin, which lacks bedded salt, is particularly likely to have been flushed of salt before high flow velocities were reached. Deming and Nunn mentioned the possibility that focused flow could have alleviated the problem, but they also noted that much of the evidence cited for topographically driven flow indicates that if such a flow did occur it was widespread rather than focused.

\section{OIL MIGRATION}

Part of the evidence presented by Bethke and others (1991) for topographically driven flow and oil migration along the sub-Kaskaskia unconformity is the occurrence of oil well beyond the most favorable and mature areas of New Albany Shale source rock. If the distribution of oil is compared to the distribution of marginally mature oil source rock in the New Albany Shale, the two are, however, almost coincident (fig. 1). The marginally mature source rock is a possible source of the oil. The extent of the marginally mature New Albany Shale source rock shown in figure 1 is based on vitrinite reflectance values of 0.5 ; however, a comparison of reflectance values of the New Albany Shale and the Herrin Coal Member of the Carbondale Formation suggests that the reflectance value of the New Albany Shale has been underestimated. The New Albany Shale and the Herrin Coal Member have similar vitrinite reflectance values even though the New Albany Shale has been more deeply buried than the Herrin Coal Member. This suggests that values of the New Albany Shale have been suppressed and that values corrected for the suppression would be about 0.6 or 0.7 (Vito Nuccio, U.S. Geological Survey, oral commun., 1993). These corrected values indicate that essentially all of the New Albany Shale is a mature potential oil source rock. If basinwide fluid migration had occurred, a close association between oil pools and potential oil source rock would not be anticipated. Thus, the relation between oil and source rock may be better evidence against long-distant migration of oil in the basin by topographically driven flow or any other mechanism than evidence for it.

\section{EVIDENCE FOR A BREACH IN THE TOPOGRAPHICALLY DRIVEN FLOW}

A striking character of the distribution of oil in the Illinois Basin is the paucity of oil between the Cottage Grove-Rough Creek-Shawneetown fault zone and the Pascola arch in contrast to the abundance of oil north of the fault zone (fig. 1). This difference could be due to water from a topographically driven flow system from the Pascola arch flushing oil south of the fault or causing a pre-migration occlusion of porosity south of the fault (Mitch Henry, U.S. Geological Survey, oral commun., 1993). Alternatively, because this is one of the most faulted parts of the world (Allen Heyl, U.S. Geological Survey, retired, oral commun., 1990), buoyancy may have caused oil to escape along any of the numerous faults. All of these interpretations indicate that there was a major difference in hydrology on opposite sides of the Cottage Grove-Rough Creek-Shawneetown fault zone and that flow from the Pascola arch, if it did occur, did not continue across the fault zone. Instead, water (and perhaps oil) more likely escaped to the surface. Although it is possible that faults conducted water across the faults in the southern part of the basin, it is also possible that any of the faults that were conducting fluids provided an opportunity for water to escape to the surface. Permian seas are believed to have covered the southern part of the Illinois Basin, whereas the Upper Mississippi Valley region was above sea level. Consequently, faults or other permeable paths to the Permian sea floor would have provided lower pressure escape routes than were available in the Upper Mississippi Valley region. Mississippi Valley-type mineralized rock vertically along faults around Hicks dome (the Illinois-Kentucky district) provides evidence for upward movement of solutions along the faults and suggests that this area was a major leak in the proposed topographically driven flow system. Ratios of bromine to chlorine in the basinal brines indicate that the basin was never flushed of its original seawater (Walter and others, 1990) and thus support the interpretation that water from the Pascola arch escaped to the surface rather than being flushed across the length of 


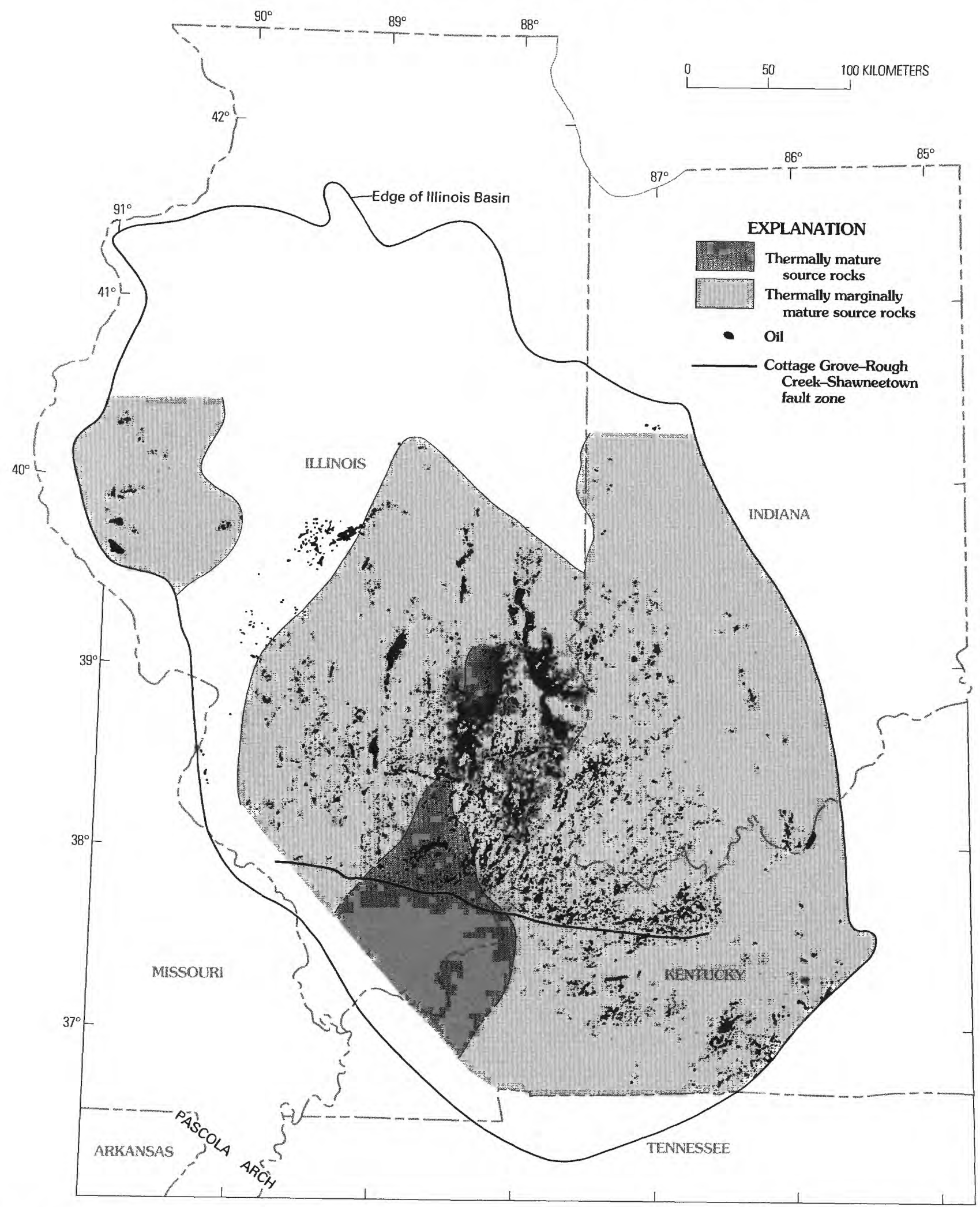

Figure 1. Distribution of oil (Buschbach and Kolata, 1990) compared to thermal maturity of New Albany source rock (Cluff and Byrnes, 1990), Illinois and surrounding area. Locations of Upper Mississippi Valley zinc-lead district, Pascola arch, and Cottage Grove-Rough Creek-Shawneetown fault zone are also shown. 
the Illinois Basin. It should be noted that bromine-chlorine data are lacking for Cambrian strata and therefore do not rule out the possibility of flow through the Mount Simon Sandstone. Such a route requires, however, the heating of a larger volume of rock than does flow along an unconformity and thus accentuates the problem of the quantity of heat. Also, limited bromine-chlorine data for Ordovician strata (Walter and others, 1990) suggest that the Ordovician rocks were not flushed, and there is no impermeable barrier between the Cambrian and Ordovician units. Consequently, rocks of both ages probably had similar hydrologic histories.

\section{IMPETUS FOR FLOW FROM THE PASCOLA ARCH}

In estimating the driving force for migration of oil, Bethke and others (1991) assumed that the Pascola arch was uplifted 300,700 , or $1,000 \mathrm{~m}$ above the northern part of the Illinois Basin. Based on the wedge-shaped thickness of the sediments younger than the Tuscaloosa Formation (which is the erosional debris from the Pascola uplift), combined with a factor for compaction of the sediments and an estimate of the slope of the sea floor as the Tuscaloosa Formation was deposited, Marcher and Stearns (1962) estimated that the maximum elevation of the arch was $300 \mathrm{~m}$ above sea level in the Late Cretaceous. From paleostream gradients (based on pebble sizes in the Tuscaloosa Formation), the arch could have been $300-600 \mathrm{~m}$ above sea level. These estimates are based on the sedimentology of the Late Cretaceous Tuscaloosa Formation, which is about 200 million years younger than the mineralization. The elevation of the arch in the Permian is not known, and, in the Permian, pre-Permian sediments may have extended farther onto the emergent Wisconsin arch than they do today. Therefore, $300 \mathrm{~m}$ of hydrologic head across the basin may be an overestimate. Even with $300 \mathrm{~m}$ of head, the calculations of Bethke and others (1991) show that buoyancy of oil is a stronger driving force than is topographically driven flow. Thus, topographically driven flow may not be necessary to account for the migration of oil from source rock to overlaying reservoir rocks. It is also not clear that the small area of the Pascola arch would capture a sufficient volume of water to flush the Illinois Basin (Dennis Kolata, Illinois State Geological Survey, oral commun., 1993).

\section{WESTWARD AND NORTHWESTWARD FLOW FROM THE APPALACHIANS}

Topographically driven flow from the northern Appalachians across the Cincinnati-Findlay arch and westward to the Upper Mississippi Valley district has also been proposed (Garven and Sverjensky, 1989), but no evidence has been presented to show that such a flow could change a meteoric water into a brine that was sufficiently hot, or saline, or metalliferous to form the Upper Mississippi Valley district. More recently, Garven and others (1993) no longer advocated flow from the northern Appalachians to the district, and they estimated that the maximum temperature of a topographically driven fluid flowing westward from the northern Appalachians was $184^{\circ} \mathrm{C}$ on the Cincinnati arch. That temperature is cooler than temperatures in the Upper Mississippi Valley district and still hundreds of kilometers from the district. Furthermore, it is based on the assumptions of a surface temperature of $20^{\circ} \mathrm{C}$ and an effective porosity of the Mount Simon Sandstone of 25 percent. (Effective porosity is the total porosity minus the water retained in small pores and on grain surfaces.) The surface temperature is important because it, together with the depth times the geothermal gradient, determines the temperature at any point in the basin and because surface temperature in a recharge area determines how much heat must be added to influxing water to bring the water to the temperature of mineralization. For a recharge area at heights of $\mathbf{3} \mathbf{~ k m}$ during the Permian, which was a period of glaciation, $20^{\circ} \mathrm{C}$ is unreasonable. The effective porosity of the basal aquifer is important because it determines how much hot water can be flushed through the ore district before influxing meteoric water begins to cool the basin. The average porosity for sandstone is about 15 percent (Kharaka and Berry, 1976). Although some sandstones have porosities as high as 25 percent, these typically are well-sorted sandstones that have not been deeply buried; both deep burial and poor sorting reduce porosity (Kharaka and Berry, 1976). The Mount Simon Sandstone is characterized, however, by poor sorting (Sargent, 1990), and, according to Garven and others (1993), the parts of the formation that contained hot water in the Permian were buried 4-7 km deep. Measurements of porosity of the Mount Simon Sandstone in Illinois (Buschbach and Bond, 1974) indicate an average of 11.8 percent and a range from 10 to 15 percent, and an average of 386 porosity measurements of the Mount Simon Sandstone in northern Indiana (Becker and others, 1978 ) is 10.8 percent. Therefore, the assumption of 25 percent effective porosity (Garven and others, 1993) is unjustified and more than doubles the amount of water likely to be available in the Mount Simon Sandstone and exaggerates the maximum temperature produced by flushing the basin.

Part of the evidence presented for large-scale topographically driven flow from the uplift of the Appalachians is the remagnetization of rocks over much of the midcontinent. Although remagnetization can be caused by thermal events, it can also be caused by chemical processes. In the case of the late Paleozoic remagnetization of the midcontinent, McCabe and Elmore (1989) presented the possibility that the migration of a hot, potassium-bearing solution triggered the conversion of smectite to illite and concomitant release of iron. This iron formed magnetite, which imparted a remagnetization on the host rock. McCabe and Elmore also noted, however, that remagnetization can be caused by 
reaction of iron minerals with hydrocarbons or by the oxidation of pyrite or siderite by near-surface solutions. Regional uplift of the midcontinent in the late Paleozoic suggests that such oxidation is reasonable. Uplift might also have initiated the migration of hydrocarbons in the late Paleozoic and caused remagnetization. Furthermore, in a study of Ordovician potassium-rich bentonites, Elliott and others (1990) found that K/Ar ages of illite-smectite astride the Cincinnati arch are older (325-290 Ma) than K/Ar ages of illite-smectite of both the Illinois and Appalachian Basins (270-250 Ma). These results do not support the regional migration of a hot, potassium-bearing solution that could have caused the remagnetization across the Cincinnati arch and throughout the midcontinent at the time of mineralization (270 Ma). At present, it is not possible to identify the cause of remagnetization in the midcontinent; thus, the remagnetization does not necessarily indicate the passage of a hot, topographically driven solution from the Appalachians at the time of mineralization in the Upper Mississippi Valley district.

As an alternative to topographically driven flow from the Pascola arch or from the northern Appalachians to the Upper Mississippi Valley district, Garven and others (1993) proposed a northwestwardly directed topographically driven flow from the southern Appalachians starting in Georgia, through central Tennessee, turning northward in the Illinois Basin, and on to the Upper Mississippi Valley district. They suggested that flow in this $1,000-\mathrm{km}$-long flow path was through the Cambrian and Ordovican aquifers at a rate of $2 \mathrm{~m}$ per year. According to their calculations, the maximum temperature, $158^{\circ} \mathrm{C}$, at a point on the northern side of the basin was attained 300,000 years after uplift; thereafter, influx of cool meteoric water placed an additional demand on the heat supply of the basin and cooled the effluent. This maximum temperature is somewhat less than the highest temperatures in the Upper Mississippi Valley district and is unrealistically high. As with flow from the northern Appalachians, Garven and others (1993) assumed an unreasonably high surface temperature of $20^{\circ} \mathrm{C}$ and an effective porosity of 25 percent. Both of these assumptions exaggerate the maximum temperature of the topographically driven flow. Furthermore, as shown in their figure 29 , the point on the north side of the basin that attained $158^{\circ} \mathrm{C}$ is more than $100 \mathrm{~km}$ from the Upper Mississippi Valley district. How much the solution would cool before it reached the district is not clear.

As with flow from the Pascola arch, although focusing of the flow might conserve heat, it creates other problems. In particular, Garven and others (1993) attributed potassic alteration, trace mineralization, and remagnetization to the same topographically driven flow as that which formed the ore deposits; however, the widespread nature of these other alterations indicates that they were not the products of focused flow. The east-west dimension of the Upper Mississippi Valley district (the dimension perpendicular to the proposed flow path) is more than $100 \mathrm{~km}$ (twice as much if outlying deposits are included) and is comparable to the width of the deep parts of the Illinois Basin. Consequently, little if any lateral focusing of hot fluids from the deep part of the basin to the district is possible. Vertical focusing of fluids is also unlikely because the basal aquifer thickens to the north.

The salinity of the mineralizing solution is an additional problem. Garven and others (1993) estimated that a 150-mthickness of salt would have to be dissolved to provide salinity of the fluids; however, no bedded salt is known to be present in the Illinois Basin, and there is no reason to believe that salt ever was present in the basin. Furthermore, dissolution of that much salt would have left indications that would not go unnoticed. In the model of Garven and others (1993), the mountains are uplifted instantaneously; thus the model does not address the problem noted by Deming and Nunn (1991) that salt would be flushed from the basin before flow was fast enough to efficiently transport heat. As with flow from the Pascola arch, bromine-chlorine ratios of pore waters in the basin indicate that the basin was not flushed, an indication contrary to topographically driven flow.

\section{WESTWARD FLOW FROM THE FINDLEY ARCH}

Early Devonian uplift of the Findley arch as impetus for topographically driven flow through the Michigan Basin and on to the Upper Mississippi Valley district has been proposed as a means of bringing potassium into the district to form potassium feldspar in Cambrian and Ordovician sediments (Duffin and others, 1989). In the Early Devonian, however, the Findley arch was only a broad swell with low relief, as was the Wisconsin arch. Consequently, there was little or no impetus for flow along the proposed path. This proposed flow does not address the Early Devonian and Permian episodes of potassic alteration in the Upper Mississippi Valley district nor does it explain the early Mississippian (361-348 Ma) age of the illitization of the St. Peter Sandstone (Ordovician) in the Michigan Basin (Barnes and others, 1989). That is, flow off the Findley arch does not explain why a potassium-bearing solution generated in the Early Devonian in the Michigan Basin caused potassic alteration in the St. Peter Sandstone in the Upper Mississippi Valley district but not in the St. Peter Sandstone in the Michigan Basin.

\section{EVIDENCE FOR A DEEP-SEATED HEAT SOURCE}

Lack of evidence for sufficiently hot fluids in the basin, evidence that basinal brines have not been flushed, and the lack of a satisfactory mechanism to transport sufficient heat from the basin leave little choice but to 
derive heat for mineralization from depths below the Upper Mississippi Valley district.

The Upper Mississippi Valley district is within a northeast-trending zone of positive magnetic anomalies extending from southeast lowa through Wisconsin to Lake Michigan north of Milwaukee (fig. 2) (Hoppe and others, 1983). The northwest boundary of this zone coincides with a marked change in the character of the gravity anomaly patterns, and a weak seismic signature correlates with the zone of anomalous magnetic intensity (Coates and others, 1983). Linear dislocations in the magnetic patterns in southern Wisconsin are interpreted as demarcating major basement faults (Heyl and King, 1966). The seismicity, magnetic anomalies, and change in the character of the gravity patterns are all suggestive of a fault zone affecting the basement rocks. In addition, the abundance of fluorite, typically 0.5 percent (Eckstein and others, 1983), in basement rocks in drillholes UPH-1, -2 , and -3 may also be indicative of deep faults. Only one grain of fluorite has been found in the Upper Mississippi Valley district (Heyl and others, 1959); however, fluorite has been found along with galena in Pint's quarry near Waterloo, Iowa (Garvin and others, 1987), and in quarries near Milwaukee, Wisconsin (Allen Heyl, oral commun., 1993). Both quarries are above the zone of positive magnetic anomalies.

Mineralized rock indicates a Permian thermal event in the area, and there is evidence for Early Devonian, Late Devonian, and Permian episodes of potassic alteration in the district (Hay and others, 1988). Faults commonly are reactivated by both compressional and extensional tectonic events and become the focus of thermal and alteration episodes. Thus, these thermal and alteration events of various ages around the Upper Mississippi Valley district may also be indicative of a fault system beneath the district.

Sverjensky and Garven (1992) believed that the Early Permian age of the mineralization in the Upper Mississippi Valley district and of the Appalachian orogeny genetically links the two via a topographically driven flow from the Appalachians despite the $700 \mathrm{~km}$ between the district and the Appalachians. Alternatively, because tectonic stress is known to propagate across continental interiors (Ziegler, 1978, 1988; Leighton and Kolata, 1990), the Permian collision of continents that raised the Appalachians might have reactivated ancient faults in the district and elsewhere across the continental interior and triggered thermal events along these faults. In support of this latter contention, although the interiors of continents are generally thought to be tectonically stable and thermally quiescent, kimberlites of Ordovician or younger age in northern Michigan (Cannon and Mudrey, 1981) and of Cretaceous age in southeastern Kansas (Heyl, 1972) indicate that episodes of thermal activity do take place well within stable interiors. Basin subsidence is also a form of tectonic and thermal activity, and, in the nearby Michigan Basin, subsidence continued into the Jurassic (Leighton and Kolata, 1990). The strike-slip character of some major faults in the Upper Mississippi

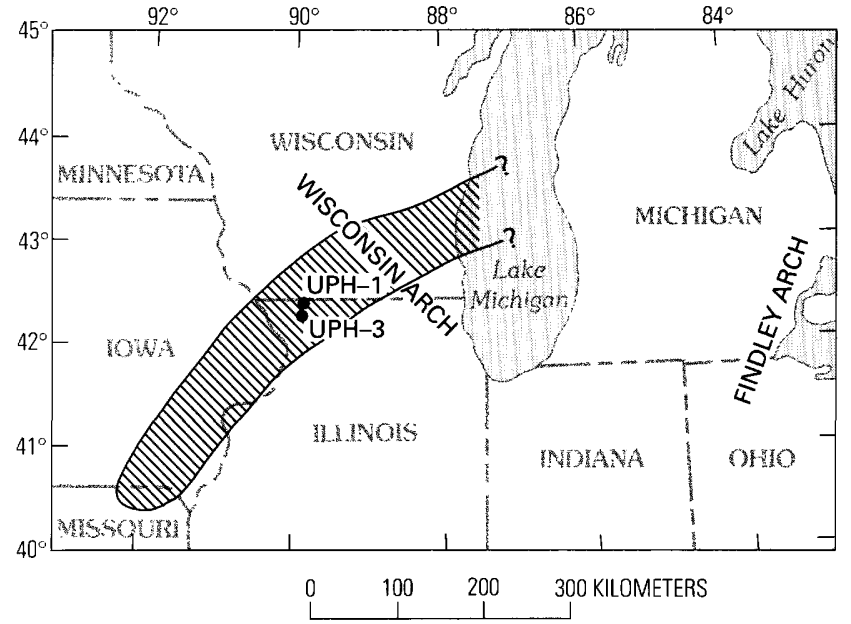

Figure 2. Locations of drillholes UPH-1 and UPH-3 and zone of positive magnetic anomalies (shaded) (modified from Hoppe and others, 1983), north-central United States. Locations of Findley and Wisconsin arches are also shown.

Valley district, with as much as $330 \mathrm{~m}$ of horizontal displacement (Heyl and others, 1959), is also an indication that stress from continental collision can be propagated well into stable cratons. Because stress related to continental movement involves the entire thickness of crustal blocks, these faults may be surface expressions of very deep rooted faults.

Fluid inclusion studies (Taylor and others, 1992) and zoning of lead isotopes and various elements around Hicks dome (Hall and Heyl, 1968) clearly indicate that mineralization in the Illinois-Kentucky district is related to a local thermal anomaly from a local intrusion (Hicks dome) spawned from a rift (the Rough Creek graben) reactivated by Permian continental collision. This conclusion undermines the argument of Sverjensky and Garven (1992) that the Permian age of both the Appalachians and the Upper Mississippi Valley district links the two via topographically driven flow. That is, considering that the Illinois-Kentucky district has the same age as the Upper Mississippi Valley district and is closer to the Appalachian-Ouachita orogeny but not related to a topographically driven flow from the Appalachian-Ouachita orogeny, then the age of the Upper Mississippi Valley district does not necessarily link the district to topographically driven flow from the Appalachian-Ouachita orogeny. If the alternative interpretation, that the temporal link among Mississippi Valley-type deposits is the initiation of thermal events along faults reactivated by Permian continental collision, is correct, then the age of the faulting in the Upper Mississippi Valley district must be Permian. According to Heyl and others (1959), faults in the district are younger than mid-Silurian and, 
from regional relationships, probably post-Pennsylvanian. Mineralized rock along the faults indicates that the faults formed prior to or during mineralization, which is Permian in age (Brannon and others, 1992). Thus, within the resolution of the data, the age of the faulting is consistent with reactivation of faults by continental collision.

\section{THERMAL CONVECTION FROM A DEEP HEAT SOURCE}

Shieh (1983) concluded that the alteration of oxygen isotopes in feldspar but not in quartz in basement rock of drillhole UPH-3 (fig. 2) indicates the passage of a solution hotter than $110^{\circ} \mathrm{C}$ and cooler than $260^{\circ} \mathrm{C}$. He suggested that the solution was a basinal solution derived from above, but he did not specify a source of heat. Alternatively, it is possible that a deep-seated heat source near the district may have driven a convection system involving basinal water (fig. 3). Such a system was proposed by Heyl and others (1959, 1974) for the Upper Mississippi Valley district, by Heyl (1972) for several Mississippi Valley districts along the 38th parallel lineament, and by Ayuso and others (1987) for Mississippi Valley-type mineralization in the Rossie district of New York. Heat for the convecting system could have been provided by a buried intrusion or, in the absence of an intrusion, by the reactivation of deep faults that conducted hot fluids from depth. Many of the world's hot springs obtain their heat by conducting surface waters along faults to high temperatures at depth and then back to the surface. In a sense, deep faults, when opened by continental-scale tectonic movements so that they are conducting water, are breaks in the insulating capacity of the Earth's crust. The greater the concentration of deep, water-conducting faults in any area, the greater the thermal anomaly that they may produce. Such proposed anomalies may explain the spatial relationship between Mississippi Valley-type deposits and large-scale strike-slip fault zones in the midcontinent (Heyl, 1972).

The exceptionally high radioactivity of basement rocks beneath the Upper Mississippi Valley district (average 46 ppm U and 114 ppm Th) (Doe and others, 1983) may have contributed to heat released during faulting. According to Fehn and others (1978), unfractured igneous rocks typically have such low permeabilities that heat generated by radioactive decay in these rocks is slowly lost by conduction without any convective heat loss. Upon fracturing, however, permeability is increased by orders of magnitude, heat is lost quickly by convection, and the overlying rocks may be heated to more than $100^{\circ} \mathrm{C}$ above ambient. The presence of highly radioactive basement rocks beneath the district and faulting concomitant with mineralization make it likely that

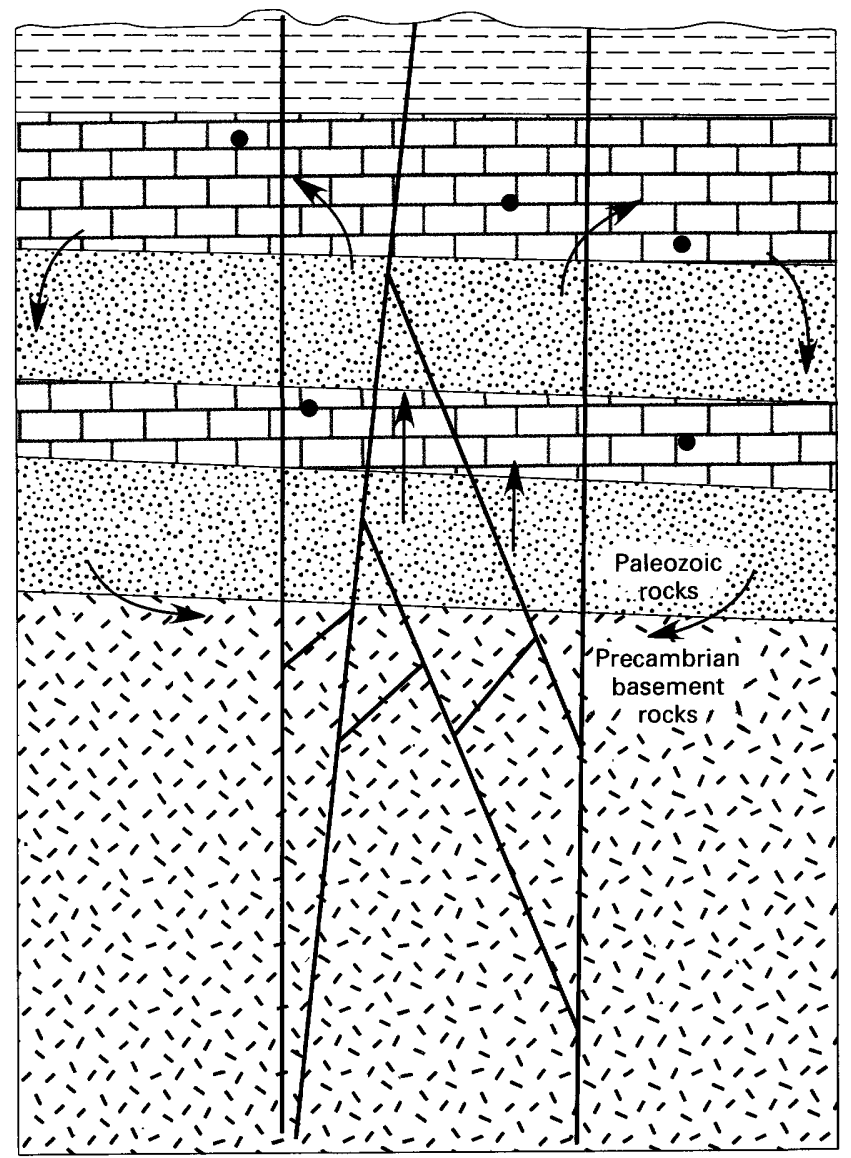

Figure 3. Schematic cross section showing faulting of uraniumand thorium-enriched basement rock beneath Upper Mississippi Valley district to release pent-up radiogenic heat, drive thermal convection of basinal brines (arrows), leach radiogenic lead from basement rocks, and deposit radiogenic lead in ores (solid circles).

the model proposed by Fehn and others (1978) contributed heat to the Upper Mississippi Valley district.

The composition of ground water $600 \mathrm{~m}$ into the Precambrian basement beneath the Upper Mississippi Valley district (Couture and others, 1983) and the presence of oil $426 \mathrm{~m}$ into the Precambrian (Couture and Seitz, 1986) indicate that basinal brines penetrated the basement to considerable depths. In the southeast Missouri district, Burstein and others (1992) suggested that basinal brines penetrated basement rocks to depths of at least $400 \mathrm{~m}$ to leach copper from the basement rocks and deposit it in the overlying Mississippi Valley-type deposits. These studies all indicate that basinal brines traveled through the basement rocks beneath the districts and thus support the possibility that thermal convection of basinal brines through the basement rocks was involved in the genesis of Mississippi Valley-type deposits. 


\section{TOPOGRAPHICALLY DRIVEN FLOW VERSUS LOCAL DEEP-SOURCED HEAT}

Sawkins (1968) used ratios of sulfate to chlorine and sodium to potassium of fluid inclusions as evidence for a blend of basinal and magmatic solutions in the genesis of Mississippi Valley-type deposits. Both basinal brines and fluids associated with intrusions, such as porphyry copper systems, may have salt contents as high or higher than Mississippi Valley-type solutions (Roedder, 1979). Thus, either type of fluid is a potential source of salinity; in contrast, meteoric water flowing along an unconformity or through a basal sandstone (the topographically driven flow model) is unlikely to become highly saline. In a thermal convection system water and salt are recirculated, whereas in topographically driven flow water and salt pass through the mineral district once and are discharged. Consequently, the total amount of salt involved in a convecting system is far less than that in the topographic flow system. Instead of requiring that hundreds of cubic kilometers of salt be dissolved to form a mineralizing solution, the initial connate water can be recycled repeatedly in a convecting system. A convecting system does not require the flushing of salt from the basin and therefore in the Illinois Basin is consistent with the observed $\mathrm{Br} / \mathrm{Cl}$ ratios.

Heat is a problem for topographically driven flow in the Upper Mississippi Valley district because computer simulations (Bethke, 1986; Deming and Nunn, 1991; Garven and others, 1993) indicate that the solution would be cooler than the observed temperature of mineralization and because the duration of mineralization (about 250,000 years) is much less than the duration of topographically driven flow pushed by the elevation of mountain ranges. Temperatures as high as $275^{\circ} \mathrm{C}$ in close proximity to Hicks dome (Cunningham and Heyl, 1980) confirm that intrusions related to Mississippi Valley-type mineralization may indeed provide the intensity of heat; even without an intrusion, faults extending to several kilometers depth will reach areas of sufficient heat to account for the temperatures of mineralization. The occurrence of porphyry copper deposits in rocks barely 1 million years old and the life spans of thermal springs of far less than 1 million years show that mineralization related to intrusions may be a short-term event (Skinner, 1979).

Regardless of the impetus for flow in the Illinois Basin, the mineralizing solution migrated through a large volume of potential host rock for ore deposits, but ore precipitated only at very specific sites in this large volume. This observation indicates that some peculiar characteristic of the sites of mineralization caused them to become mineralized. That characteristic was very probably the presence of organic matter, a universal component of Mississippi Valley-type deposits (see summary in Spirakis, 1986). By acting as a reductant, source of carbon dioxide, source of organic acids, and substrate for bacterial metabolism, organic matter triggers the precipitation of a variety of types of minerals (sulfides, disulfides, sulfates, carbonates, and fluorite), all at the same specific sites (Spirakis and Heyl, 1993). Precipitation at specific sites provides another constraint on fluid flow in that the solution must retain its ore-forming capacity until it reaches these sites. According to the topographically driven flow model applied to the Upper Mississippi Valley district, rainwater entered the sediments half a kilometer or more above sea level, plunged to several kilometers below sea level, and then ascended slowly while traveling several hundred or $1,000 \mathrm{~km}$ laterally. It is unlikely that throughout these travels the mineralizing solutions did not encounter a suitable environment in which to precipitate ore (presumably concentrations of organic matter) until the district was reached. It is much more likely that suitable sites to form ore were not restricted to the district but that a convecting thermal flow system was confined to the district. In other words, the bounds of the districts are defined by the limits of the thermal flow, and the sites of mineralization within the districts are the locations of concentrations of organic matter.

McKnight (1967) pointed out that radiogenic lead- and potassium-rich solutions are produced from alkalic magmas typical of continental interiors, and he suggested that such magmas might be related to the genesis of Mississippi Valley-type deposits. As an alternative source of potassium, according to Giggenbach (1984) potassic minerals tend to dissolve at elevated temperatures and precipitate on cooling. Hence, even without an intrusion, the change in temperature in a thermal convection system related to faults could cause the potassic alteration associated with Mississippi Valley-type deposits. Radiogenic lead also does not require an intrusion. Doe and others (1983) concluded that the basement rocks in the vicinity of the Upper Mississippi Valley district were leached of radiogenic lead (probably at the time of mineralization) and were a likely source of at least some of the lead for the ores. A thermal convecting system in the vicinity of the district involves basinal brines just as does the topographically driven flow. Hence, the brines in a thermal convecting system should be just as capable of leaching lead from the basement rocks as the brines in topographically driven flow; however, a thermal convecting system in the vicinity of the district would not have had the opportunity to derive lead from outside the district. In contrast, a solution migrating under topographically driven flow for hundreds of kilometers during hundreds of thousands of years would have had ample opportunity to become saturated with lead long before reaching the district. Thus, it seems unlikely that a topographically driven solution would have leached lead in the vicinity of the district.

In topographically driven flow, fluids are seeking the easiest access to the surface. The presence of saline solutions and oil in the Precambrian basement in drillhole UPH-3 
beneath the edge of the Upper Mississippi Valley district indicates that basinal brines flowed downward into the basement. Such a path is difficult to reconcile with topographically driven flow because it is unlikely that the easiest escape route for a solution less than $1 \mathrm{~km}$ below the surface at the Precambrian-Cambrian contact would involve a detour of more than $1 \mathrm{~km}$ farther downward into the Precambrian. The present lack of communication between freshwater in the Mount Simon Sandstone and saline water in the basement (Couture and Seitz, 1986) suggests that the Precambrian does not provide a highly permeable flow path. Although flow through the basement is unlikely in topographically driven flow, it is precisely what is expected in a thermal convecting system.

\section{CONCLUSION}

Although a local deep-seated source of heat has not been proven for mineralization in the Upper Mississippi Valley district, the tectonic setting is permissive of such a source and various lines of evidence are supportive. In contrast, there are multiple reasons to doubt that mechanisms to deliver heat from the basin, either topographically driven flow or other processes, apply to this district. A local deep-seated heat source is more than adequate for the observed mineralization; it is compatible with the local leaching of radiogenic lead; it provides a source of potassium whether an intrusion is present or not; and, by recirculating saline basinal brines, a convection system driven by a local heat source (such as the heat released from fracturing of a highly radioactive granite) does not require an unreasonable amount of salt. The presence of basinal brines to a depth of $1.3 \mathrm{~km}$ (deepest sample analyzed) in drillhole UPH-3 and a minimum estimate of the depth during mineralization in the Upper Mississippi Valley district show that basinal brines penetrated at least $1.5 \mathrm{~km}$ beneath the surface, as would be expected in a thermal convecting system but not in a topographically driven flow system or in other systems that invoke dewatering of a basin.

Instead of using topographically driven flow to account for the synchronous formation of Mississippi Valley-type deposits and other alteration events within the continental interior, I propose that continental collision may have simultaneously reopened faults throughout the midcontinent; thermal anomalies due to circulation of basinal brines along these faults then provided the conditions needed to transport elements to concentrations of organic matter in sediments where Mississippi Valley-type deposits formed. Thus, locating deep faults is a logical step in exploring for Mississippi Valley-type districts. These deep faults could have triggered the emplacement of intrusions such as Hicks dome, and the thermal anomalies associated with the faults may at least locally be related to potassic alteration, silicification, oil generation, oil migration, vitrinite reflectance, remagnetization, conversion of smectite to illite, generation of organic acids, secondary porosity, annealing of fission tracks, and trace mineralization. Thus, the reactivation of ancient faults by plate tectonics may have an important influence on the diagenesis of sediments at many locations throughout the midcontinent.

\section{REFERENCES CITED}

Ayuso, R.A., Foley, N.K., and Brown, C.E., 1987, Source of lead and mineralizing brines for Rossie-type $\mathrm{Pb}-\mathrm{Zn}$ veins in the Frontenac axis area, New York: Economic Geology, v. 82, p. 489-496.

Barnes, D.A., Girard, J-P., and Aronson, J.L., 1989, K/Ar age of illite cementation of the St. Peter Sandstone, Michigan Basin-Implications for the thermal-burial history and hydrocarbon emplacement: Geological Society of America Abstracts with Programs, v. 21, p. A159.

Becker, L.E., Hreha, A.J., and Dawson, T.A., 1978, Pre-Knox (Cambrian) stratigraphy in Indiana: Indiana Geological Survey Bulletin 57, $72 \mathrm{p}$.

Bethke, C.M., 1986, Hydrologic constraints on the genesis of the Upper Mississippi Valley mineral district from Illinois basin brines: Economic Geology, v. 81, p. 233-249.

Brannon, J.C., Podosek, F.A., and McLimans, R.K., 1992, Alleghenian age of the Upper Mississippi Valley zinc-lead deposit determined by Rb-Sr dating of sphalerite: Nature, v. 356, p. 509-511.

Burstein, I.B., Shelton, K.L., Hagni, R.D., and Brandom, R.T., 1992, Mobilization of copper by MVT fluids penetrating igneous basement rocks - Sulfur isotopes studies of the Precambrian Boss-Bixby $\mathrm{Fe}$ - $\mathrm{Cu}$ deposits, southeast Missouri: Geological Society of America Abstracts with Programs, v. 24, p. A234.

Buschbach, T.C., and Bond, D.C., 1974, Underground storage of natural gas in 1973: Illinois State Geological Survey, Illinois Petroleum, v. 101, 71 p.

Buschbach, T.C., and Kolata, D.R., 1990, Regional setting of Illinois Basin, in Leighton, M.W., Kolata, D.R., Oltz, D.F., and Eidel, J.J., eds., Interior cratonic basins: American Association of Petroleum Geologists Memoir 51, p. 29-55.

Cannon, W.F., and Mudrey, M.G., 1981, The potential for diamond-bearing kimberlite in northern Michigan and Wisconsin: U.S. Geological Survey Circular 842, p. A1-A16.

Cathles, L.M., and Smith, A.T., 1983, Thermal constraints on the formation of Mississippi Valley-type lead-zinc deposits and their implications for episodic basin dewatering and deposit genesis: Economic Geology, v. 78, p. 983-1002.

Cluff, R.M., and Byrnes, A.P., 1990, Lopatin analysis of maturation and petroleum generation in the Illinois basin, in Leighton, M.W., Kolata, D.R., Oltz, D.F., and Eidel, J.J., eds., Interior cratonic basins: American Association of Petroleum Geologists Memoir 51, p. 425-454.

Coates, M.S., Haimson, B.C., Hinze, W.J., and Van Schmus, W.R., 1983, Introduction to the Illinois deep hole project: Journal of Geophysical Research, v. 88, no. B9, p. 7267-7275.

Couture, R.A. and Seitz, M.G., 1986, Movement of fossil pore fluids in granite basement, Illinois: Geology, v. 14, p. 831-834. 
Couture, R.A., Seitz., M.G., and Steindler, M.J., 1983, Sampling brine in cores of Precambrian granite from Northern Illinois: Journal of Geophysical Research, v. 88, no. B9, p. 7331-7334.

Cunningham, C.G., and Heyl, A.V., 1980, Fluid inclusion homogenization temperatures throughout the sequence of mineral deposition in the Cave-in-Rock area, southern Illinois: Economic Geology, v. 75, p. 1226-1231.

Damberger, H.H., 1971, Coalification pattern of the Illinois basin: Economic Geology, v. 66, p. 488-494.

Deming, D., and Nunn, J.A., 1991, Numerical simulations of brine migration by topographically driven recharge: Journal of Geophysical Research, v. 96, no. B2, p. 2485-2499.

Doe, B.R., Stuckless, J.S., and Delevaux, M.H., 1983, The possible bearing of the granite of the UPH deep drill holes, northern Illinois, on the origin of Mississippi Valley ore deposits: Journal of Geophysical Research, v. 88, no. B9, p. 7335-7345.

Duffin, M.E., Lee, M., Dev. Klein, G., and Hay, R.L., 1989, Potassic diagenesis of Cambrian sandstones and Precambrian granitic basement in UPH-3 deep hole, Upper Mississippi Valley, U.S.A.: Journal of Sedimentary Petrology, v. 59, p. 848-861.

Eckstein, Y., Dahl, P.S., and Vitaliano, C.J., 1983, Petrographic and physical factors controlling thermal conductivity of granitic rocks in Illinois deep drill holes UPH 1, 2, and 3: Journal of Geophysical Research, v. 88, no. B9, p. 7381-7385.

Elliott, W.C., Aronson, J.L., Roden, M.K., and Miller, D.S., 1990, The formation of illite in the Appalachian basin-A test of the fluid expulsion hypothesis: Geological Society of America Abstracts with Programs, v. 22, p. A62.

Fehn, U., Cathles, L.M., and Holland, H.D., 1978, Hydrothermal convection and uranium deposits in abnormally radioactive plutons: Economic Geology, v. 73, p. 1556-1566.

Garven, G., Ge, S., Person, M.A., and Sverjensky, D.A., 1993, Genesis of stratabound ore deposits in the midcontinent basins of North America; 1, The role of regional groundwater flow: American Journal of Science, v. 293, p. 497-568.

Garven, G., and Sverjensky, D.A., 1989, Hydrology of regional flow systems associated with the formation of Mississippi Valley-type ore deposits in the mid-continent: Geological Society of America Abstracts with Programs, v. 21, p. A9.

Garvin, P.L., Ludvigson, G.A., and Ripley, E.M., 1987, Sulfur isotope reconnaissance of minor metal sulfide deposits fringing the Upper Mississippi Valley zinc-lead district: Economic Geology, v. 82, p. 1386-1394.

Giggenbach, W.F., 1984, Mass transfer in hydrothermal alteration systems-A conceptual approach: Geochimica et Cosmochimica Acta, v. 48, p. 2693-2711.

Gize, A.P., and Barnes, H.L., 1987, The organic geochemistry of two Mississippi Valley-type lead-zinc deposits: Economic Geology, v. 82, p. 457-470.

Hall, W.E., and Heyl, A.V., 1968, Distribution of minor elements in ore and host rock, Illinois-Kentucky fluorite district and Upper Mississippi Valley zinc-lead district: Economic Geology, v. 63, p. 655-670.

Hatch, J.R., Heyl, A.V., and King, J.D., 1986, Organic geochemistry of hydrothermal alteration, basal shale and limestone beds, Middle Ordovician Quimbys Mill Member, Platteville Formation, Thompson-Temperly zinc-lead mine, Lafayette County, Wisconsin, in Dean, W.E., ed., Organics and ore deposits: Denver Regional Exploration Geologists Society, Proceedings, p. 93-104.
Hay, R.L., Lee, M., Kolata, D.R., Matthews, J.C., and Morton, J.P., 1988, Episodic potassic diagenesis of Ordovician tuffs in the Mississippi Valley area: Geology, v. 16, p. 743-747.

Heyl, A.V., 1972, The 38th parallel lineament and its relationship to ore deposits: Economic Geology, v. 67, p. 879-894.

1983, Geologic characteristics of three major Mississippi Valley districts, in Kisvarsanyi, G., Grant, S.K., Pratt, W.P., and Koenig, J.W., eds., International conference on Mississippi Valley-type lead-zinc deposits: Rolla, University of Missouri, p. 27-60.

Heyl, A.V., Hosterman, J.W., and Brock, M.R., 1964, Clay-mineral alteration in the Upper Mississippi Valley zinc-lead district: Clays and Clay Minerals National Conference, 12th, Atlanta, 1963, Proceedings; New York, MacMillan, p. 445-453.

Heyl, A.V., and King, E.R., Aeromagnetic and tectonic interpretation of the Upper Mississippi Valley zinc-lead district: U.S. Geological Survey Bulletin, 1242-A, p. A1-A16.

Heyl, A.V., Landis G.P., and Zartman, R.E., 1974, Isotopic evidence for the origin of Mississippi Valley-type mineral deposits-A review: Economic Geology, v. 69, p. 992-1006.

Heyl, A.V., Jr., Agnew, A.F., Lyons, E.J., and Behre, C.H., Jr., 1959, The geology of the Upper Mississippi Valley zinc-lead district: U.S. Geological Survey Professional Paper 309, 310 p.

Hoppe, W.J., Montgomery, C.W., and Van Schums, W.R., 1983, Age and significance of Precambrian basement samples from northern Illinois and adjacent states: Journal of Geophysical Research, v. 88, B9, p. 7276-7286.

Kharaka, Y.K., and Berry, F.A.F., 1976, Chemistry of waters expelled from sands and sandstones, in Chilingarian, G.V., and Wolf, K.H., eds., Compaction of coarse-grained sediments, II: Developments in Sedimentology, v. 18B, p. 41-68.

Lavery, N.G., and Barnes, H.L., 1971, Zinc dispersion in the Wisconsin zinc-lead district with an appendix by K.H. Wedepohl on Zinc and lead in common sedimentary rocks: Economic Geology, v. 66, p. 226-242.

Leighton, M.W., and Kolata, D.R., 1990, Selected interior cratonic basins and their place in the scheme of global tectonics - A synthesis, in Leighton, M.W., Kolata, D.R., Oltz, D.F., and Eidel, J.J., eds., Interior cratonic basins: American Association of Petroleum Geologists Memoir 51, p. 720-797.

Marcher, M.V., and Stearns, R.G., 1962, Tuscaloosa Formation in Tennessee: Geological Society of America Bulletin, v. 73, p. 1465-1386.

McCabe, C., and Elmore, R.D., 1989, The occurrence and origin of Late Paleozoic remagnetization in the sedimentary rocks of North America: Review of Geophysics (supplement), v. 27, p. 471-494.

McKnight, E.T., 1967, Bearing of isotopic composition of contained lead on the genesis of Mississippi Valley ore deposits, in Brown, J.S., ed., Genesis of stratiform lead-zinc-barite-fluorite deposits (Mississippi Valley-type deposits)-A symposium: Economic Geology Monograph 3, p. 392-399.

McLimans, R.K., 1977, Geological, fluid inclusion and stable isotope studies of the Upper Mississippi Valley zinc-lead district, southwest Wisconsin: College Station, Pennsylvania State University, $\mathrm{Ph} . \mathrm{D}$. thesis, $175 \mathrm{p}$.

Pinckney, D.M., and Rafter, T.A., 1972, Fractionation of sulfur isotopes during ore deposition in the Upper Mississippi Valley zinc-lead district: Economic Geology, v. 67, p. 315-328. 
Roedder, E., 1979, Fluid inclusions as samples of ore fluids, in Barnes, H.L., Geochemistry of hydrothermal ore deposits (2nd ed.): New York, John Wiley, p. 684-737.

Sangster, D.F., 1989, Thermal comparison of MVT deposits and their host rocks: Geological Society of America Abstracts with Programs, v. 21, p. A7.

Sargent, M.L., 1990, Sauk sequence-Cambrian system through Lower Ordovician series, in Leighton, M.W., Kolata, D.R., Oltz, D.F., and Eidel, J.J., eds., Interior cratonic basins: American Association of Petroleum Geologists Memoir 51, p. 75-86.

Sawkins, F.J., 1968, The significance of $\mathrm{Na} / \mathrm{K}$ and $\mathrm{Cl} / \mathrm{SO}_{4}$ ratios in fluid inclusions and subsurface waters, with respect to the genesis of Mississippi Valley-type ore deposits: Economic Geology, v. 63, p. 935-942.

Shieh, Y., 1983, Oxygen isotope study of Precambrian granites from the Illinois deep hole project: Journal of Geophysical Research, v. 88, no. B9, p. 7300-7304.

Skinner, B.J., 1979, The many origins of hydrothermal mineral deposits, in Barnes, H.L., ed., Geochemistry of hydrothermal ore deposits (2nd ed.): New York, John Wiley, p. 1-21.

Spirakis, C.S., 1986, Occurrence of organic carbon in Mississippi Valley-type deposits and an evaluation of processes involving organic carbon in the genesis of these deposits, in Dean, W.E., ed., Organics in ore deposits: Denver Regional Exploration Geologists Society, Proceedings, p. 85-95.
Spirakis, C.S., and Heyl, A.V., 1993, Organic matter (bitumen and other forms) as the key to localisation of Mississippi Valley-type ores, in Parnell, J., Kucha, H., and Landais, P., eds., Bitumens in ore deposits: New York, Springer-Verlag, p. 382-398.

Sverjensky, D.A., 1981, The origin of a Mississippi Valley-type deposit in the Viburnum trend, southeast Missouri: Economic Geology, v. 76, p. 1848-1872.

Sverjensky, D.A., and Garven, G., 1992, Tracing great fluid migrations: Nature, v. 356, p. 481-482.

Taylor, C.S., Rowan, E.L., Goldhaber, M.B., and Hayes, T.S., 1992, A relationship between Hicks Dome and temperature zonation in the fluorite in the Illinois-Kentucky fluorspar district, a fluid inclusion study, in Goldhaber, M.B., and Eidel, J.J., eds., Mineral resources of the Illinois basin in the context of basin evolution: U.S. Geological Survey Open-File Report 92-1, p. 62-64.

Walter, L.M., Stueber, A.M., and Huston, T.J., 1990, Br-Cl-Na systematics in the Illinois basin fluids - Constraints on fluid origin and evolution: Geology, v. 18, p. 315-318.

Ziegler, P.A., 1978, Northwestern Europe-Tectonic and basin development: Geologie en Mijnbouw, v. 57, no. 4, p. 589-626. 1988, Evolution of the Arctic-North Atlantic and the western Tethys: American Association of Petroleum Geologists Memoir 43, 198 p.
Published in the Central Region, Denver, Colorado

Manuscript approved for publication February 2, 1995

Edited by Judith Stoeser

Graphics by Henry F. Williams

Photocomposition by Patricia L. Wilber 
